\title{
Morphotectonics and evolutionary controls on the Pearl River Canyon system, South China Sea
}

\author{
Weiwei Ding $\cdot$ Jiabiao $\mathbf{L i} \cdot \mathbf{J u n} \mathrm{Li} \cdot$ Yinxia Fang $\cdot$ \\ Yong Tang
}

Received: 4 December 2012/ Accepted: 19 March 2013/Published online: 20 April 2013

(C) The Author(s) 2013. This article is published with open access at Springerlink.com

\begin{abstract}
The Pearl River Canyon system is a typical canyon system on the northern continental slope of the South China Sea, which has significant implications for hydrocarbon exploration. Through swath bathymetry in the canyon area combined with different types of seismic data, we have studied the morphotectonics and controlling factors of the canyon by analyzing its morphology and sedimentary structure, as well as the main features of the continental slope around the canyon. Results show that the Pearl River Canyon can be separated into three segments with different orientations. The upper reach is NW-oriented with a shallowly incised course, whereas the middle and lower reaches, that are located mainly in the Baiyun Sag, have a broad U-shape and have experienced consistent deposition. Seventeen deeply-cut canyons have developed in the slope north of the Baiyun Sag, playing an important role in the sedimentary processes of the middle and lower reaches of the Pearl River Canyon. These canyons display both asymmetrical V- and U-shapes along their lengths. Numerous buried channels can be identified below the modern canyons with unidirectionally migrating stacking patterns, suggesting that the canyons have experienced a cyclic evolution with several cut and fill phases of varying magnitude. These long established canyons, rather than the upper reach of the Pearl River Canyon, are the main
\end{abstract}

W. Ding · J. Li $(\bowtie) \cdot$ Y. Fang $\cdot$ Y. Tang

The Second Institute of Oceanography, State Oceanic

Administration, 32\# Baochubei Road, Hangzhou 310012, China

e-mail: jbli@sio.org.cn

W. Ding

e-mail: wwdingsio@yahoo.com.cn

J. Li

China Institute for Marine Affairs, State Oceanic Administration,

Beijing, China conduits for the transport of terrigenous materials to the lower slope and abyssal basin during lowstand stage, and have contributed to the formation of vertically stacked deep-water fans in the middle reach. Canyon morphology is interpreted as a result of erosive sediment flows. The Pearl River Canyon and the 17 canyons in the slope area north of the Baiyun Sag probably have developed since the Miocene. Cenozoic tectonics, sea level change and sediment supply jointly control the morphology and sedimentary structure. The middle and lower reaches of the Pearl River Canyon developed on the paleo-terrain of the Baiyun Sag, which has been a persistently rapid depositional environment, receiving most of the materials transported via the canyons.

Keywords Pearl River Canyon - Morphotectonics . Sedimentation $\cdot$ Controlling factors $\cdot$ South China Sea

\section{Introduction}

Submarine canyons are common features incised into the continental shelves and slopes of all continental margins worldwide (Farre et al. 1983; Hagen et al. 1996; Klaus and Taylor 1991; Puig et al. 2003; Deptuck et al. 2003; Harris and Whiteway 2011). Most canyons are located entirely on the upper slope, although there are also some large canyons with heads that deeply indent the shelf break. They are generally V-shaped (in an erosional setting) or U-shaped (in a depositional setting). Submarine canyons are interesting for their prominence among topographic features on continental margin sea floors. In the last few decades, surveys of submarine canyons have been advanced by the development of new techniques for deep-sea surveying, such as multi-beam bathymetric mapping and very high- 
resolution seismic profiling. Studies have revealed that canyons not only shape the present morphology of continental margins but also act as the main conduits for transferring terrestrial sediments toward the deep sea and often feed a river's fan system (Babonneau et al. 2002; Li et al. 2012). A number of these shelf-indenting canyons are associated with large, mud-rich, deep-sea fan systems such as the Amazon, Mississippi, Indus, and Bengal fans (Kottke et al. 2003; Oliveira et al. 2007), or they can act as a trap for the along-shelf transport of sediment, as is the case with the Monterey Canyon, and be modern depositional centers, especially in the modern sea level high stand (Carson et al. 1986; Granata et al. 1999). Still, canyon genesis and evolution are far from understood, even though corresponding deep-sea fans have been thoroughly studied. In addition to constituting an important archive for documenting the sedimentation history of an area, submarine canyons are also studied as modern analogs for deepwater hydrocarbon reservoirs because of their association with sand-rich turbidites (Stow and Mayall 2000; Posamentier and Kolla 2003; Fuh et al. 2009), especially those with deep sea fan systems (Liu et al. 2006; Peng et al. 2004, 2006).

The northern continental slope of the South China Sea extends northeast from the southeastern end of the Taiwan Island to the eastern end of the Xisha Trough. It is dissected by numerous canyons, including the Pearl River, South Taiwan Bank, and Penghu canyons, each of which is fed by several tributaries (Fig. 1). Most of these canyons start at the shelf-break or slightly landward from it, and have changed the geomorphology of the northern continental slope of the South China Sea. The unique and notable exception is the Pearl River Canyon, a feature that is deeply incised into the shelf landward of the shelf break. As the largest canyon system in the northern continental margin of the South China Sea, the Pearl River Canyon is connected to the youngest channel-levee system in the Pearl River Delta on the wide continental shelf, extending more than $200 \mathrm{~km}$ from the Chinese coast. After capturing several tributaries near the shelf-break, the Pearl River Canyon continues basinward as a broad channel within the Baiyun Sag of the Pearl River Mouth Basin. Compared with other canyons on passive margins with extensive deep-water fans at the canyon mouth, such as the Amazon, Mississippi, Indus, and Bengal fans (Kottke et al. 2003; Oliveira et al. 2007; Harris and Whiteway 2011), the Pearl River Canyon is featured with well developed deep-water fan systems in the middle (the Baiyun $\mathrm{Sag}$ ), which have been well studied as a result of investigations leading to the great hydrocarbon discoveries of the last 20 years (Pang et al. 2007; Zhou et al. 2009). The scale, the distinct morphology, the remarkable effects in connecting the continental shelf and deep sea area, and the special sedimentary structure, make the Pearl River Canyon be an ideal place for the sedimentary process study on passive margin. Great efforts have been made to understand its morphology, sedimentation, and formation in the last decades. Jin (1989) has described the general morphology of the Pearl River Canyon, including its origin, extension direction, length, and changes in shape with depth. Liu et al. (2006) compared the erosional and depositional features of various canyons in the continental slope area of the Baiyun Sag based on detailed analyses of the sequence stratigraphy of the area. On the basis of similar work Zheng et al. (2007) proposed that a drop event in global sea level at 13.8 Ma triggered the development of the Pearl River Canyon, together with the associated deep-water fan system. Canyon morphology is interpreted to be a result of erosive sediment flows along the entrenched axial thalweg that caused downcutting in the canyon bottom and instability of the canyon walls. This led to enlargement of the canyon and expansion by headward erosion. Zhu et al. (2010) documented changes in morphology, sedimentation, and gradients of several canyons in the northern continental slope area of the Baiyun Sag and discussed the relationships between depositional mode and paleoceanographic circulation. Ding et al. (2010) suggested that the formation of the Pearl River Canyon was related to the abundance of sediments carried by the paleo-Pearl River, based on analysis of and comparisons between the geomorphology and tectonic features of the Pearl River Canyon and other canyons in the northern continental slope. The research described above contributed much to understanding the nature of the Pearl River Canyon. However, the former lack of high-resolution multi-beam and multi-channel seismic data in this area hindered detailed morphological studies. The age, origin and influences of Cenozoic tectonics, sea level changes, terrestrial rivers, and ocean currents remain a matter of speculation.

In this paper, we use Pearl River Canyon system to define our study area, for this canyon system consists of several canyons on the upper slope and one trunk channel in deep water. A mechanism for canyon system evolution and the factors that controlled it are proposed based on the analysis of the detailed morphologies and the sedimentary structures, as well as the main features of the continental margin around the canyon system. This study is based on investigations of the canyon area that collected swath bathymetry and different types of seismic data.

\section{Geological setting}

The study area lies mostly within the Baiyun Sag, in the southern part of the Pearl River Mouth Basin (PRMB) and close to the oceanic crust. The basement rocks of the Baiyun Sag have been sampled by 78 wells so far. They mainly consist of Cretaceous and Jurassic granites in the 


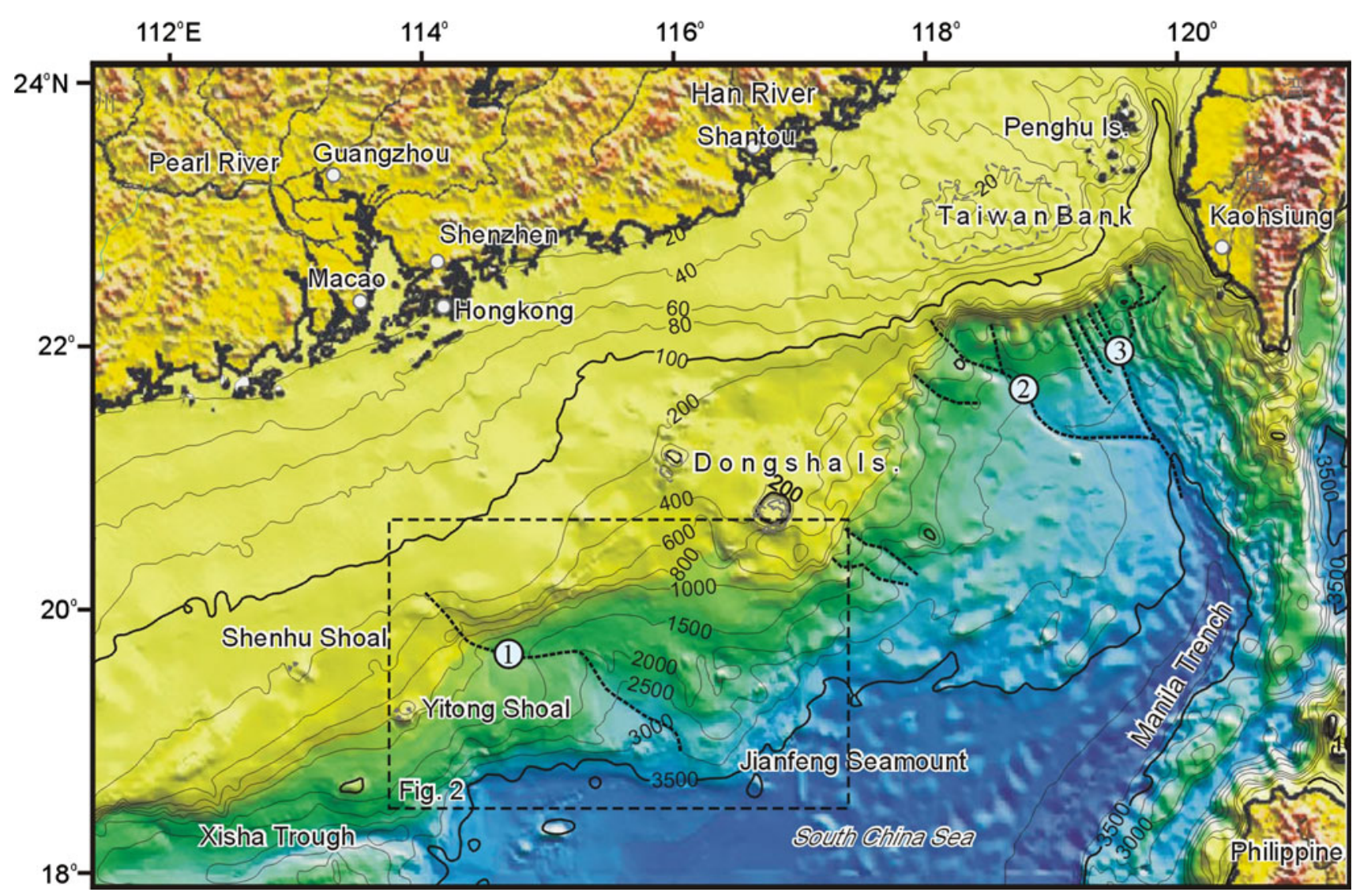

Fig. 1 Geomorphologic map of the northern continental margin of the South China Sea (black dotted lines are major submarine canyons and gullies: 1 the Pearl River Canyon, 2 the South Taiwan Bank Canyon, 3 Penghu Canyon. The framed area is the area covered by multi-beam data

central and northern region, Mesozoic unmetamorphosed sedimentary rocks in the east, and Paleozoic (?) quartzite and other metamorphic rocks in the west (Zhou et al. 1995). Previous studies suggested that the Baiyun Sag experienced rifting and post-rifting stages divided by a break-up unconformity (Pang et al. 2007; Zhou et al. 2009). The rifting stage occurred over several episodes, roughly from the Late Cretaceous or Paleogene to Early Oligocene. The post-rifting stage lasted roughly from the Late Oligocene to the present (see Fig. 2 for details).

The Baiyun Sag is the largest and deepest sag of the PRMB with Cenozoic sediments exceeding $11 \mathrm{~km}$ in thickness (Zhou et al. 2009). From bottom to top, the sediments change from fluvial-lacustrine-neritic shelf facies of the Paleogene sys-rift stage to deep-water slope sediments of the Neogene post-rift stage. The Paleogene to Lower Oligocene strata consist of fluvial-lacustrine sediments in faulted sags, among which the Eocene Wenchang and Enping formations contain dark lacustrine mudstones. Sediments in the Upper Oligocene Zhuhai Formation are transitional and deltaic. Neogene strata consist of marine formations that constitute a generally transgressional sequence (see Fig. 2 for more details).
The tectonic structures that affect the Tertiary sediments in the Baiyun Sag are faults and grabens with a predominantly NNE-SSW orientation, and secondary structures with NW-SE trends (Ru and Pigott 1986; Luedmann and Wong 1999). The ENE-WSW-running normal faults dip toward the center of subsidence, and cluster in large numbers. The NW-SE-running faults are regional lithospheric faults that were active throughout the Tertiary and offset the ENE-WSW-striking faults (Sun et al. 2005, 2009).

\section{Data and methods}

A bathymetric data set was collected over the region of $113^{\circ} 50^{\prime}-117^{\circ} 25^{\prime} \mathrm{E}, 18^{\circ} 15^{\prime}-20^{\circ} 15^{\prime} \mathrm{N}$, during several cruises by the Second Institute of Oceanography, State Oceanic Administration, between 2003 and 2005. Multi-beam echosounder systems, including an Elac Bottom Char MK II dual multibeam echosounder on board R/V Ocean Surveillance Ship 49, a SeaBat multibeam echosounder on board R/V Xiangyanghong 9, and a SeaBeam multibeam echosounder onboard R/V Dayang YiHao were used jointly. 
Fig. 2 Seismic stratigraphy, lithology, major tectonic events and sea level change curve in the research area
Table 1 Acquisition parameters for bathymetric data used in this study

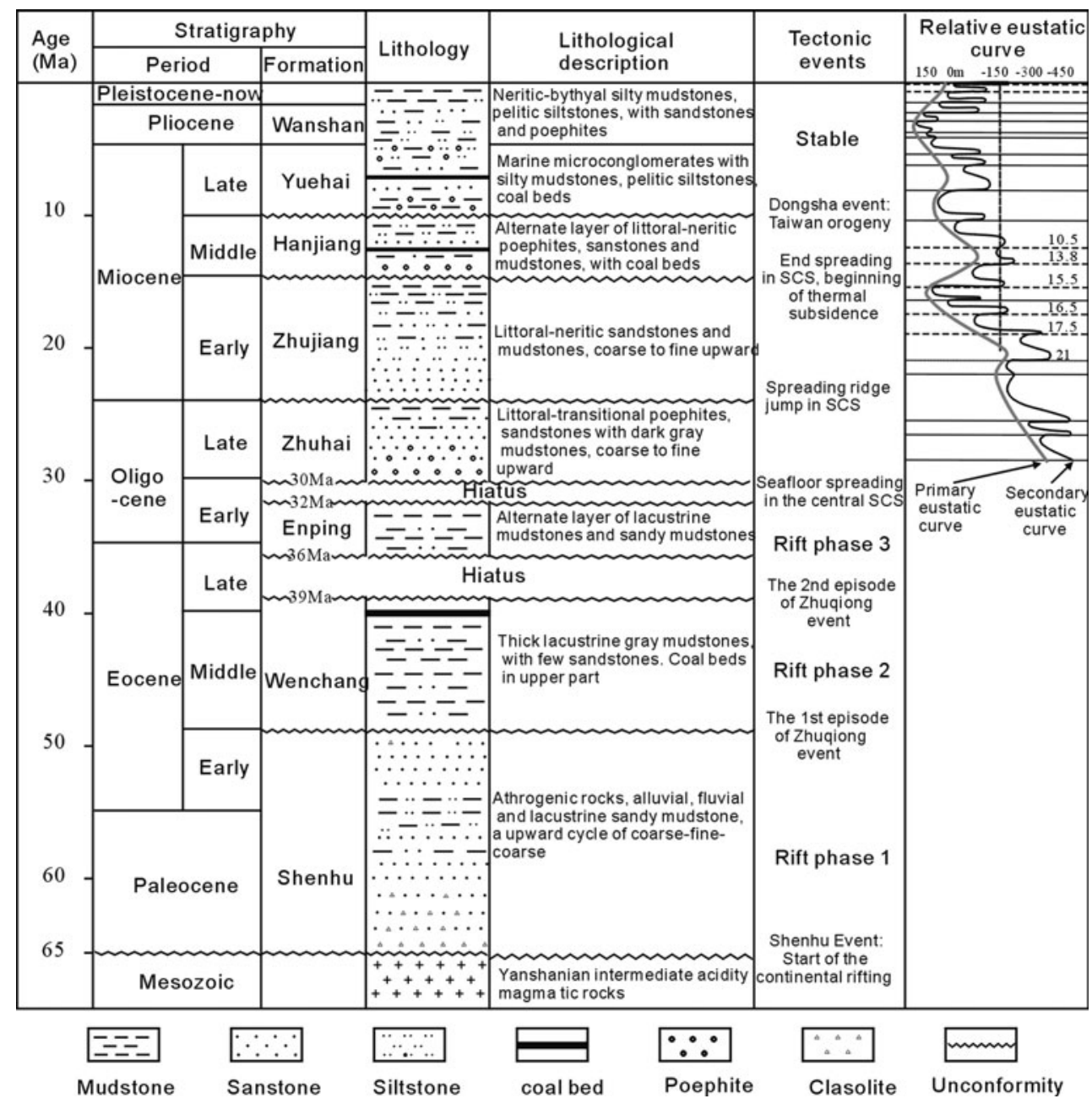

\begin{tabular}{lcllr}
\hline $\begin{array}{l}\text { Multibeam } \\
\text { Echosounder }\end{array}$ & $\begin{array}{l}\text { Working } \\
\text { frequency }(\mathrm{kHz})\end{array}$ & $\begin{array}{l}\text { Numbers of beams } \\
\text { in each Ping }\end{array}$ & $\begin{array}{l}\text { Beam } \\
\text { angle }\end{array}$ & $\begin{array}{l}\text { Maximum emission } \\
\text { beam angle }\left(^{\circ}\right)\end{array}$ \\
\hline Elac Bottom Char MK II & 50 & 126 & $1.5^{\circ} \times 1.5^{\circ}$ & 150 \\
SeaBat & 240 & 100 & $1.5^{\circ} \times 1.5^{\circ}$ & 50 \\
SeaBeam & 12 & 151 & $2^{\circ} \times 2^{\circ}$ & 150 \\
\hline
\end{tabular}

Acquisition parameters for these multibeam echosounders are listed in Table 1. During deep tow profiling, a dense line offset was used to reduce the opening angles of the beams and produce higher-resolution images, while still covering the complete area. The acoustic velocity of the multibeam echosounder was corrected using the acoustic velocity profile acquired by Cable Thermal Detector. Bathymetric data were processed routinely onboard during the survey, using the Generic Mapping Tools software and the academic software MB-System from Lamont-Doherty Earth Observatory. To show morphostructural features more clearly, the data were processed to generate shaded relief images after being edited (Fig. 2).
The seismic data were collected from other cruises. Acquisition parameters for the seismic profiles are listed in Table 2. Locations are shown in Fig. 1. Published industrial drilling data (Peng et al. 2004, 2006) and data from an Ocean Drilling Program (ODP) borehole (ODP Site 1148), that reached the Oligocene (Wang et al. 2000), were used to interpret seismic sequences against regional lithostratigraphic units. In addition, we incorporated published stratigraphic schemes from the study area (Zhou et al. 1995, 2009; Luedmann and Wong 1999; Pang et al. 2007; Sun et al. 2009) (Fig. 2). Our approach to identify sequence boundaries was mostly based on seismic characteristics, including reflection frequency, amplitude and continuity, and reflection termination (onlap, downlap and truncation). 
Table 2 Acquisition parameters for seismic profiles used in this study

\begin{tabular}{lll}
\hline Profile names & E & A, B, C, D \\
\hline Acquired by & SCSIO & CNOOC \\
Acquisition date & 2001 & 1989 \\
Streamer channels & 48 & 240 \\
Record length (s) & 12.0 & 5.0 \\
Sampling rate (ms) & 2 & 2 \\
Receiver interval (m) & 25.0 & 12.5 \\
Shot interval (m) & 50 & 25 \\
Airgun volume $\left(\mathrm{in}^{3}\right)$ & 1,520 & 3,946
\end{tabular}

SCSIO, South China Sea Institute of Oceanology, Chinese Academy of Sciences; CNOOC, China National Offshore Oil Corporation

\section{Morphological characteristics}

General morphology

The area covered by multi-beam data spans the continental shelf, the continental slope, and the oceanic basins from 100 to $3,600 \mathrm{~m}$ in water depth. The topography of the continental shelf is relatively flat, and the continental shelf break is at a water depth of nearly $200 \mathrm{~m}$ (Wang et al. 2008), whereas the topography in the continental slope area is complicated and shows highly changeable vertical gradients (between $2^{\circ} 47^{\prime}$ and $6^{\circ} 20^{\prime}$ ). Two positive relief units, the Yitong Shoal in the west and the Dongsha Islands in the northeast, are distinct features (Fig. 3). Steep scarps and canyons have developed with erosional channels and ridges in between. Most of these canyons are located in the slope area north of the Baiyun Sag and south of the Yitong Shoal, and generally have a NW orientation of $340^{\circ}$. The northern canyons feature linear courses without branched heads, whereas the southern ones show multiple heads. The boundary between continental slope and oceanic basin is the 3,500-m isobath, and the topography in the oceanic basin is relatively simple with only gradual changes in water depth. Many other positive relief features are found in the continental slope and oceanic basin, such as the Jiangfeng Seamount east of the Pearl River Canyon, the EWoriented seamount chains west of the end of the Pearl River Canyon, and seamount islands or chains in the abyssal basin.

\section{Cross-sectional morphology of the Pearl River Canyon}

The Pearl River Canyon is the most remarkable morphologic unit in the research area. The course of the Pearl River Canyon displays three distinct trends (Fig. 3). In its head region at the shelf edge and the upper slope, the canyon shows an initial NW-SE course. However, upon entering the Baiyun Sag at a water depth of about 1,000 m, it is sharply diverted to a predominantly $\mathrm{E}-\mathrm{W}$ direction. The course changes to NW-SE again at $18^{\circ} 42^{\prime} \mathrm{N}, 116^{\circ} \mathrm{E}$ and a depth of $2,100 \mathrm{~m}$, and flows into the deep sea at a depth of about $3,500 \mathrm{~m}$. The two abrupt shifts in course allow us to divide the morphological features of the canyon into three domains: an upper reach, a middle reach, and a lower reach.

Because of a lack of multi-beam data, the head of the canyon is not shown on our map. Previous research has shown that the upper reach might extend $48 \mathrm{~km}$ landward following a SE trend before changing to an E-W orientation (Jin 1989). Bathymetric cross sections in the head region show a wide U-shaped trough with some small incisions in the floor (Profiles 1 and 2 in Fig. 4).

At around 1,000 m, the canyon's course turns E-W and keeps the U shape. The middle reach narrows (in Fig. 4, the canyon width in Profile 3 is about $25 \mathrm{~km}$, but it is about $30 \mathrm{~km}$ in Profile 2), and the walls become steeper (Profiles 3 and 4 in Fig. 4). Escarpments (about 150-200 m high) can be identified in both the south and north of the canyon from the multi-beam geomorphologic map. Note that the canyon shape is not symmetrical. With increasing water depth, the middle reach becomes wider and extends about $200 \mathrm{~km}$ before changing to a NW direction at a water depth of about $2,700 \mathrm{~m}$.

Further downstream, below a depth of $2,700 \mathrm{~m}$, the lower reach turns to a NW orientation with widths between 25 and $40 \mathrm{~km}$ (Profiles 5, 6, and 7 in Fig. 4), showing a broad, flat, and U-shaped cross-section. Near the canyon mouth the lower reach becomes obviously narrower owing to blocking seamounts. Profile 8 shows that the width of the canyon is about $30 \mathrm{~km}$ at a water depth of $3,200 \mathrm{~m}$, and in Profile 9 the width is reduced to $17 \mathrm{~km}$ with an axial incision in the bottom.

Canyons in the slope area north of the Baiyun Sag

Seventeen sub-linear, sub-parallel, regularly spaced, modern submarine canyons have developed in the continental slope area north of the Baiyun Sag, extending from their inceptions at a water depth of $\sim 450 \mathrm{~m}$ to their terminations at $\sim 1,500 \mathrm{~m}$ (Fig. 3). Most of these canyons are 


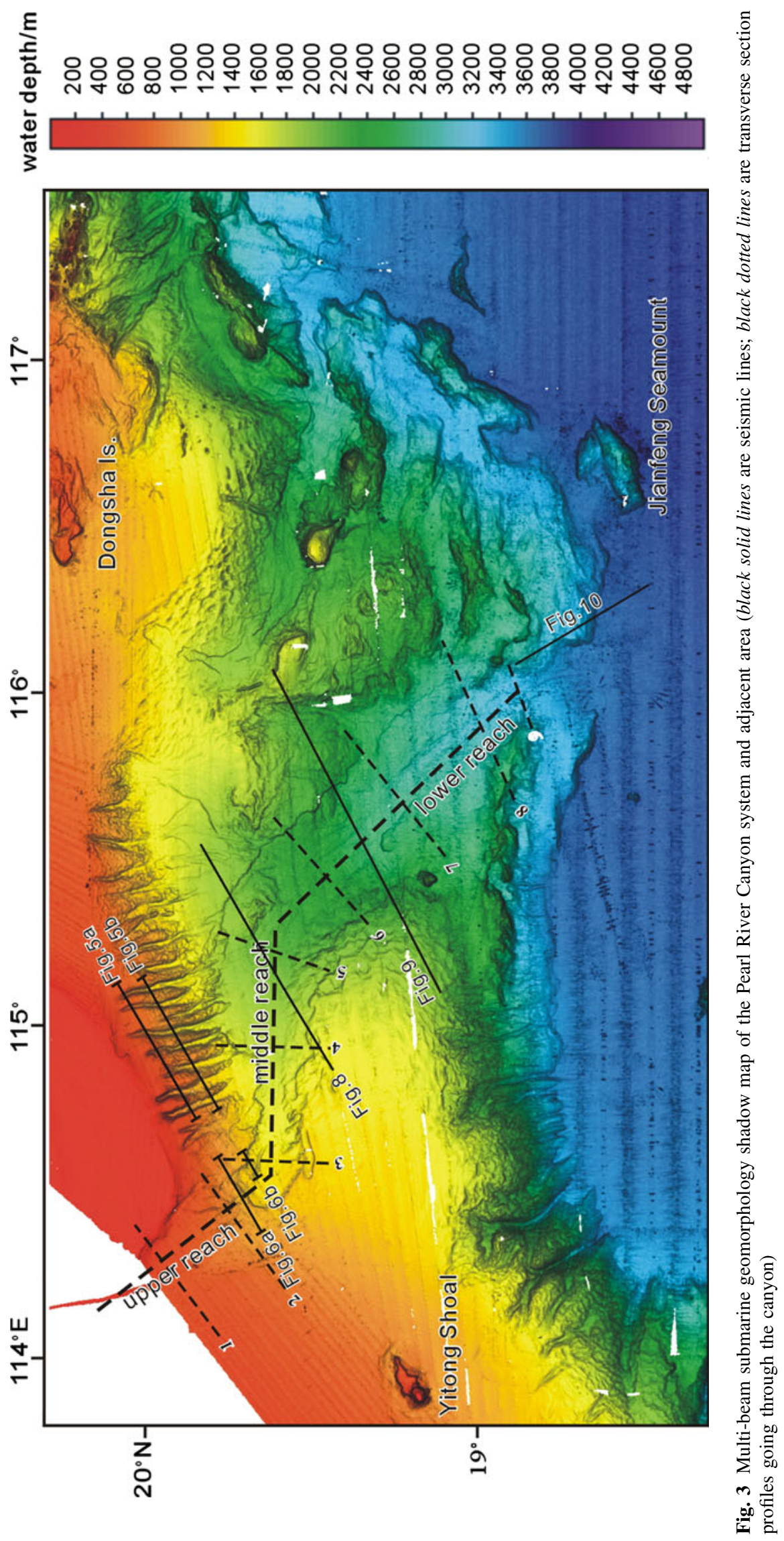


Fig. 4 Transverse section

profiles of the canyon (refer to

Fig. 3 for the locations)
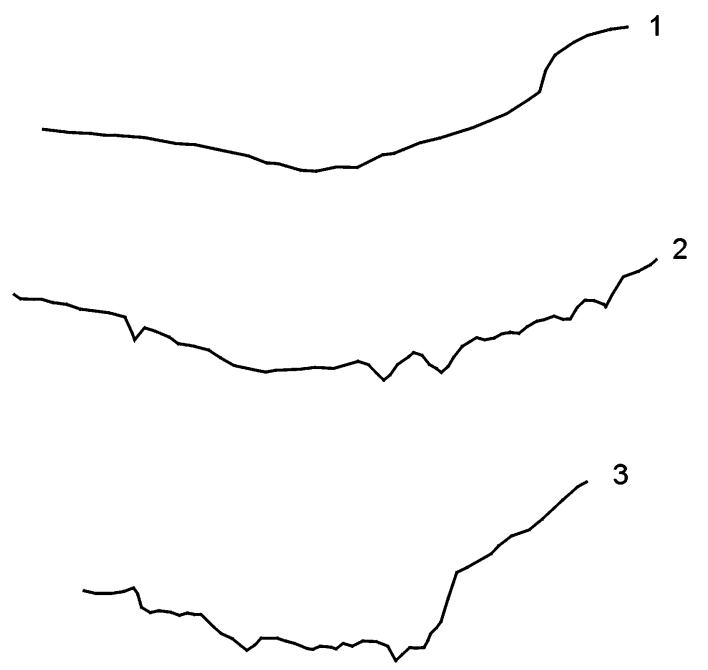

3
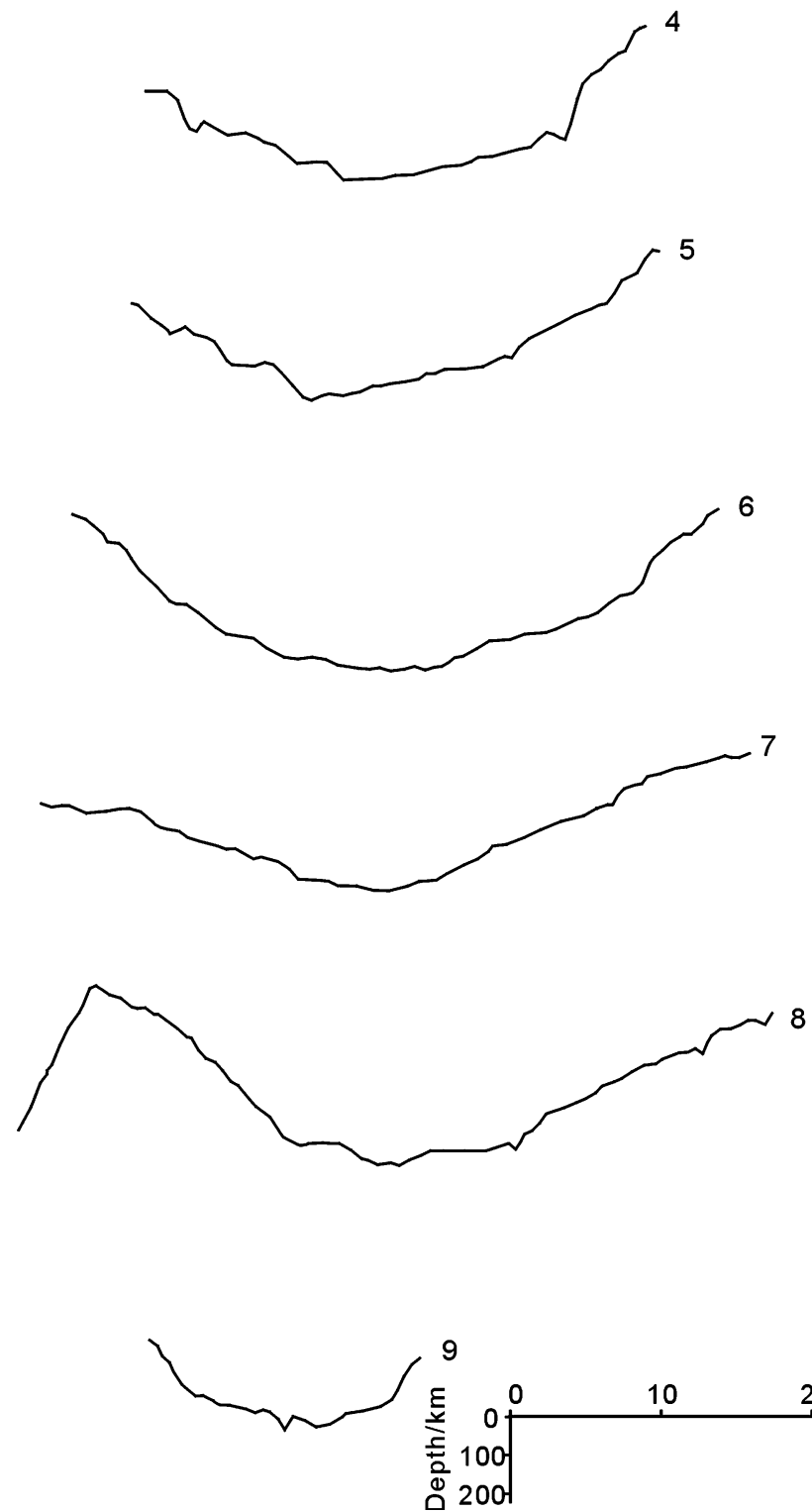
orientated $\mathrm{N}-\mathrm{S}$, but have some deflection to the east close to their distal terminations. These canyons are about $30-60 \mathrm{~km}$ long and $1-5.7 \mathrm{~km}$ wide, and exhibit some 50-300 m of relief. The walls on both sides are smooth and steep. Nine canyons in the west join directly into the Pearl River Canyon, whereas the other eight in the east converge between two morphological elevations on the lower continental slope, before finally joining the main course.

The morphological features of these canyons vary significantly as thalweg gradients change down dip. Two seismic profiles cross the upper and lower segments of canyons 4, 5, 7 and 8 (Fig. 5) display different morphological features. The segments near the head are dominantly erosional with a $\mathrm{V}$-shaped profile and thalweg gradients ranging from $3^{\circ}$ to $6.8^{\circ}$. The crests between canyons are smooth and rounded in the shallower water close to the shelf break (Fig. 5a). Further to south the thalweg gradients decrease to $0.5^{\circ}-3^{\circ}$. These canyons are much wider and deeper, and $\mathrm{U}$ shape, showing a combination of erosional and depositional features (Fig. 5b). The crests between the canyons become sharp and rough as a result of slumping and sliding on the canyon walls.

\section{Sedimentary structures}

Upper reach and canyons in the slope north of the Baiyun Sag

Two seismic sections cross the upper reach of the Pearl River Canyon in the west (Fig. 6). The irregular cross-sectional form of the upper reach in Fig. 6a does not show a typical Vor U-shaped morphology. Obvious differences exist between the near-seafloor deposits separated by the Pearl River Canyon. Sediments in the west flank are characterized by lowfrequency, high-amplitude continuous reflections, whereas the east flank features high-frequency, medium-amplitude reflections that thicken to the east, which might indicate an eastern origin. Channels with low relieves inside the canyon course show characteristics similar to the east flank. They should be sedimentary relicts incised by channels instead of sediments transported by the canyon. Unlike the flanks with continuous parallel reflections, deposits below the main canyon course are observed in bending folds. Multiple stacked buried channels could be identified, indicating a composite cut-and-fill history. Most of the modern canyon and the buried channels have a course that is small in scale (no wider than $2.6 \mathrm{~km}$ ) and an incised valley that is shallow (no deeper than $50 \mathrm{~m}$ ). The stacking patterns of buried channels are irregular, which might imply that the mass transport was relatively weak in the upper reach of the Pearl River Canyon.

Several normal faults can be identified below the canyon course. They have remained active until very recently, and some even reach the sea floor (Fig. 6b). Some faults are coincident with the buried channels (Fig. 6a), or the modern canyon (Fig. 6b).

Compared with the course of the Pearl River Canyon in the east, the canyons in the slope area north of the Baiyun Sag cut much more deeply into the sediments (up to $200 \mathrm{~m}$ ) with more unique sedimentary structures, which also vary significantly as the thalweg gradient changes downdip (Fig. 6). Detailed interpretation of Canyon 5, for instance, shows sedimentary features in different segments. A seismic section across the canyon head shows that the canyon walls abruptly terminate the surrounding sub-parallel-bedded, inclined reflections, which are interpreted as progradational deposits in an outer shelf to upper slope setting (Figs. 6, 7a). Here, Canyon 5 is characterized by a well-defined $\mathrm{V}$-shaped trough without any deposits in the bottom, whereas further downstream, Canyon 5 is U-shaped and broadened. Figure $7 \mathrm{~b}$ shows truncations of parallel reflections against the east wall. Stepped and curved surfaces on the west wall indicate that sliding or slumping of the strata in areas of the middle reach may have resulted in widening of the canyon. Slumped sediments of the west canyon wall are characterized by chaotic facies. The flat reflection at the canyon bottom is considered to be a cut-andfill feature. Sediments transported from eroded walls nearby or from up reach have been deposited and have partially filled the canyon bottom, resulting in a flat surface. The increases of width and incision of the canyon may imply a greater intensity of erosion or down-cutting of the canyon floor and slumping and sliding on the walls to widen the canyon.

Seismic sections across this area also show a complex stratigraphic architecture beneath the modern canyons with episodically infilled channels (Fig. 5), as in other submarine canyon systems worldwide, which indicates a complex history of canyon cut-and-fill development, including erosion, infilling, migration and merging (Mayall et al. 2006; McHargue et al. 2011; He et al. 2012). The formation history of these buried channels is very long, with some of them even predating the 16.5 Ma sequence boundary (Fig. 5). Thalwegs of these buried channels are stacked and progressively offset toward the northeast, with more erosion on their eastern flanks. Again we use canyon 5 as an example (Fig. 7c). The east flank of the canyons features termination alignments due to the truncation of lateral reflections, which makes it easy to distinguish the erosional surfaces on the flank. Medium- to high-amplitude reflections can be identified at the bottom of the thalweg. These thalweg deposits might be formed during or shortly after the channel was cut. In contrast, on the west flank, a series of seismic reflections dip towards the canyon thalweg, marking the systematic lateral migration of the canyons. These lateral accretionary packages are characterized by low to medium amplitudes, a high degree of continuity, and a parallel or sub-parallel relationship with each other. They developed exclusively in the western flanks of the 


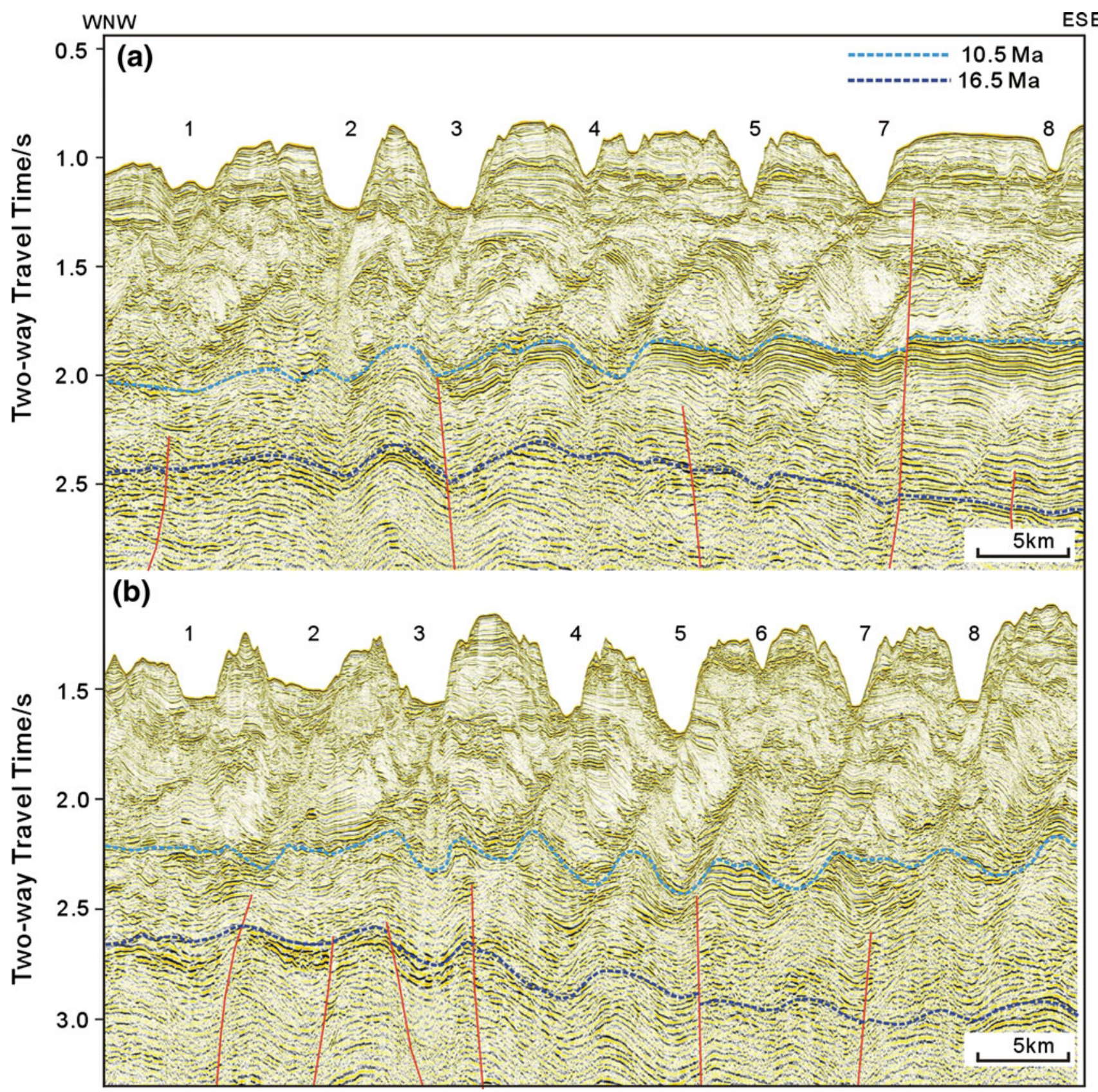

Fig. 5 Seismic sections cross 8 canyons in the slope area north of the Baiyun Sag. The canyon head show typical V shape with steep walls (Canyon 4, 5, 7 and 8 in the upper section). While further down stream the canyons are wider and deeper in U shape. Crests between canyons are much sharper and rougher. Most of the canyons show

canyons and merge with thalweg deposits in the central parts of the canyons. These buried channels all form a northeastward migrating stacking pattern.

This stacking pattern also seems to be more vertically oriented in the lower segment. In the upper segment, the horizontal shift can reach $\sim 8 \mathrm{~km}$ (in Canyon 5 , this corresponds to the period since $10.5 \mathrm{Ma}$, Fig. $5 \mathrm{a}$ ), which is reduced to $\sim 5 \mathrm{~km}$ basinward (since $10.5 \mathrm{Ma}$ in Canyon 5 , asymmetric morphology with more erosion in the east wall. Episodic developed buried channels could be identified beneath the modern canyons with vertical stacked pattern. See Fig. 3 for the locations. Note Fig. 7 is drawn from this figure

Fig. 5b). Such changes in morphology and stacking pattern are quite common in adjacent canyons.

\section{Middle reach}

The middle reach of the Pearl River Canyon lies totally within the Baiyun Sag. With the decrease of slope gradients, 

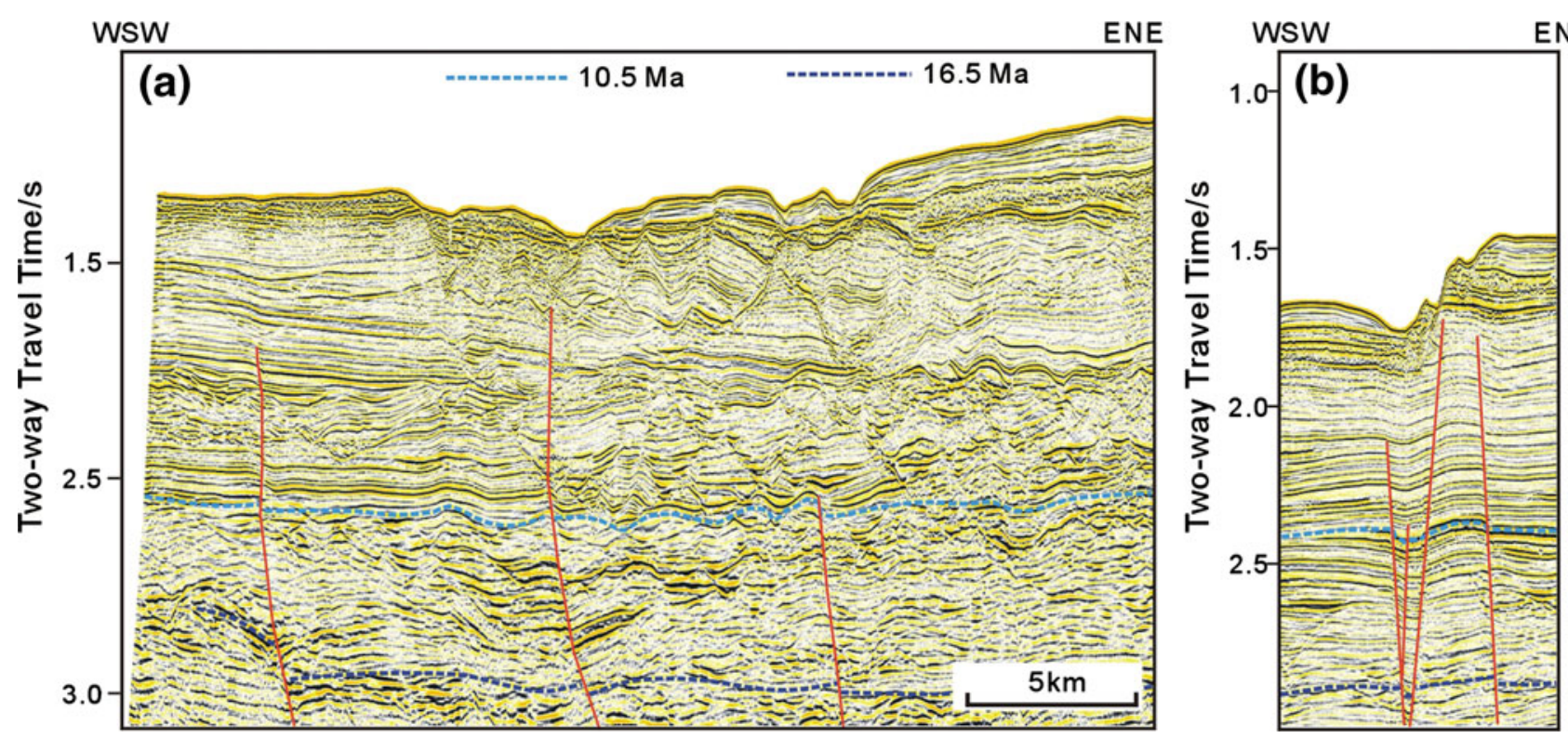

Fig. 6 Seismic sections cross the upper reach of the Pearl River Canyon. Section a shows irregular morphology without typical V or $\mathrm{U}$ shape. Buried channels could be identified beneath with random distribution. Some normal faults are coincident with the buried channel, even control the modern course, as shown in section b. See Fig. 3 for locations

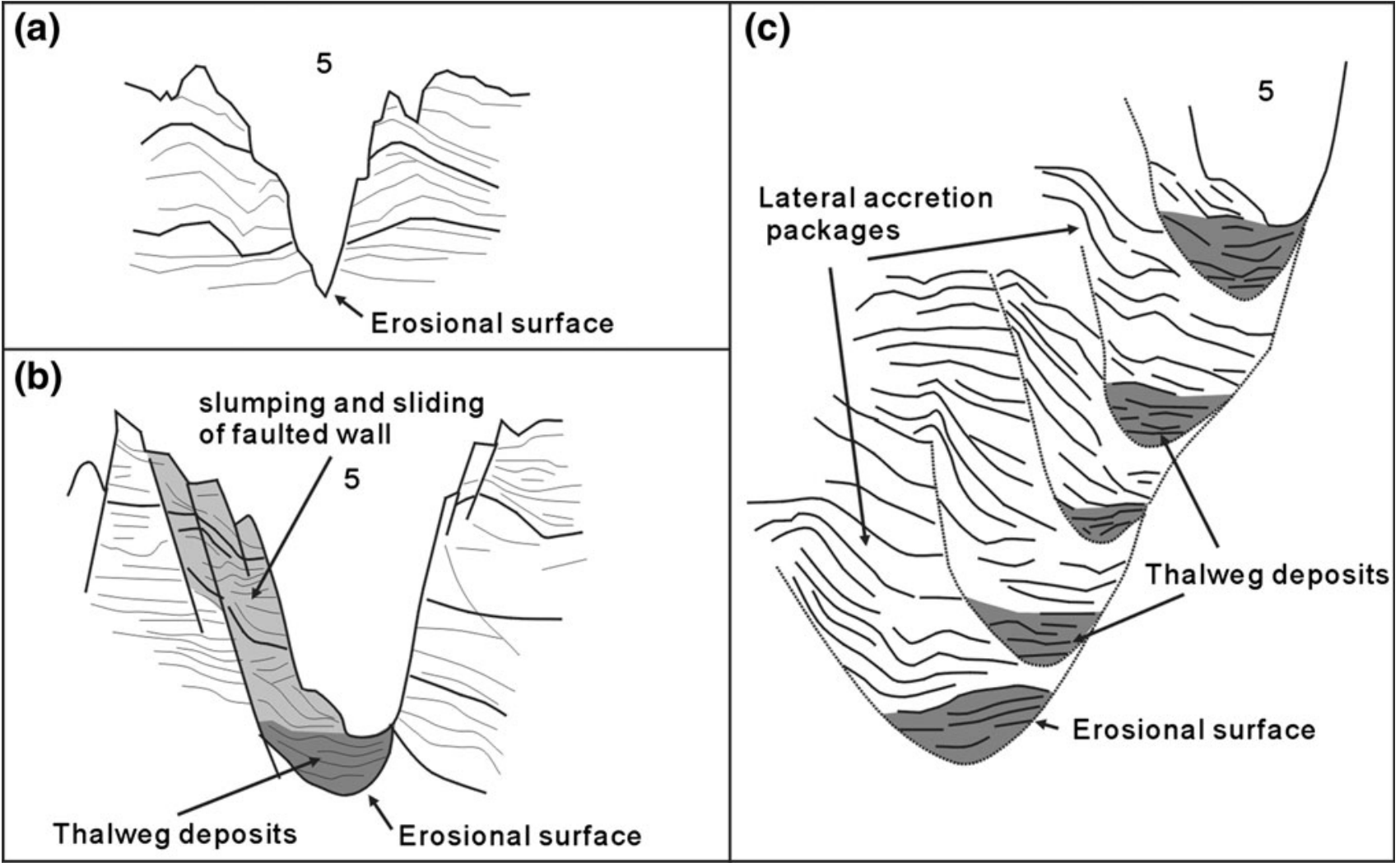

Fig. 7 Detailed interpretation of sedimentary structure of Canyon 5. a the canyon head; $\mathbf{b}$ the lower segment; $\mathbf{c}$ buried channels

this part of the canyon has sedimentary structures that are distinct from the upper reach. A seismic section that crosses the middle reach in a WSW-ENE orientation shows a typical rifted-graben with several normal faults (Fig. 8). In general, the Paleogene sediments are fault-controlled and preserve the signature of a restricted rift formed by crustal 


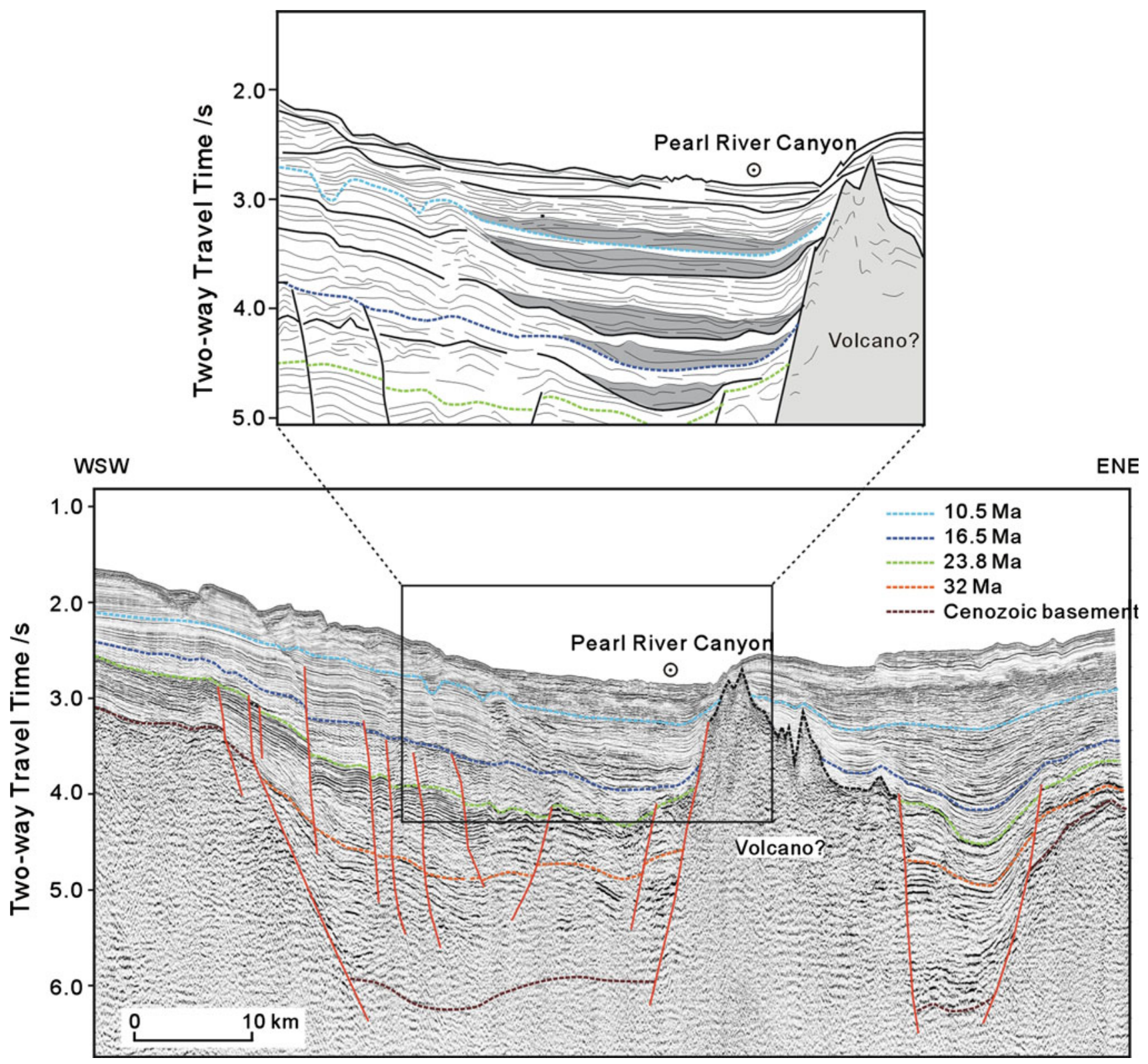

Fig. 8 Seismic section crosses the middle reach of the Pearl River Canyon. Detailed interpretation (upper) shows the vertical stacked sedimentary fans. See Fig. 3 for location

extension. In contrast, the Neogene sediments exhibit broad subsidence. A giant basement highstands in the middle of the region with internal chaotic reflections that indicate a volcanic origin. The sediments near this basement high bend strongly, implying a late volcanic intrusion (at least after $10.5 \mathrm{Ma}$ ). In this profile, the thalweg of the canyon is not distinct, but probably lies in the lowest part of the seafloor. Seismic images below the present continuous reflections show strata that are almost parallel to the seafloor. No erosion has been noticed in the surface layer except in occasional buried channels below, suggesting a filling-dominated situation.
Hydrocarbon explorations and related research have discovered a huge deep-water fan system in this area (see the interpretation of Fig. 8 above). Seismic images identify numerous stacked low-stand fans formed since the Miocene (mainly between 21 and $10.5 \mathrm{Ma}$ ). These typical lenticular sedimentary fan features have low frequencies, medium to high amplitude and good continuity, with both sides down lapping on the sequences below. We argue that these multiple vertically stacked overlapping deep-water fans have good corresponding relationships with the group of canyons in the slope area north of the Baiyun Sag. During periodic sea level drops, an abundant sediment supply from the paleo-Pearl River 


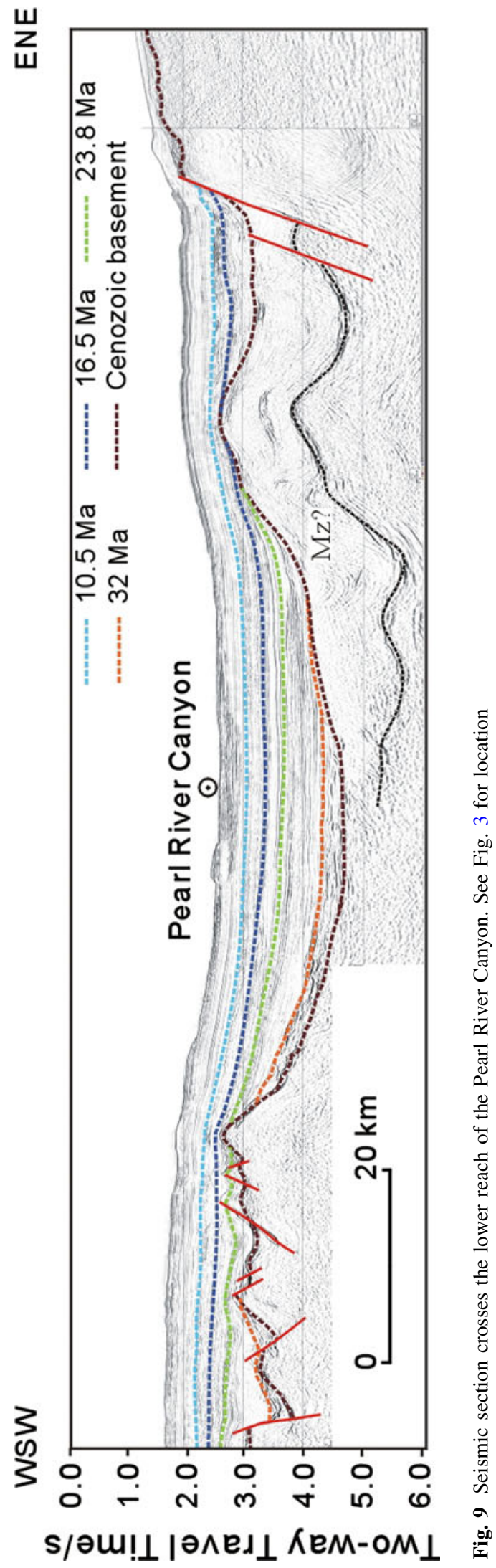

would be transported through these canyons and deposited in the Baiyun Sag owing to persistent subsidence, resulting in vertically stacked deep-water fans in this area. These deepwater fans are consistent with the supplementary budget which proposed by Clift (2006) and Clift et al. (2002b), indicating a maximum sediment delivery during the middle Miocene.

\section{Lower reach}

Figure 9 crosses the lower reach of the Pearl River Canyon. Interpretation shows a broad graben with limited fault control. The Cenozoic deposits here are plate-shaped. The Pearl River Canyon has no obvious thalweg, but below the sea floor, the seismic images present continuous parallel reflections. Neither erosion in the surface layer nor buried channels are apparent. The lower reach of the Pearl River Canyon is dominated by long-term subsidence and deposition.

The Pearl River Canyon merges into the abyssal basin at $\sim$ 3,400 $\mathrm{m}$ water depth, as shown in Fig. 10 that crosses the canyon mouth with a NW-SE orientation. A basement high separates the continental slope from the abyssal basin. Internally chaotic reflections and the overall shape both imply a volcanic origin. Seismic images in the abyssal basin show low to middle frequencies, good continuity, and parallel reflections, indicative of typical deep marine facies. Several medium- to high-amplitude wedge-shaped sedimentary bodies lie at the foot of the slope with thickness decreasing toward the ocean (see the upper section of Fig. 10). These sedimentary bodies are between 4 and $8 \mathrm{~km}$ in length and are no more than $0.1 \mathrm{~s}$ thick. We propose that they accumulated from sediments transported via the Pearl River Canyon. Compared with typical deep-sea fans that form at canyon mouths on passive margins, such as the Avon fan near the Niger Delta (Olabode and Adekoya 2008), or the Zaire deep-sea fan at the end of the Zaire Canyon (Babonneau et al. 2002), the fan of the Pearl River Canyon is relatively small in scale. We suggest that most of the terrigenous sediments transported through the Pearl River Canyon have been captured by the Baiyun Sag. The seamount near the end of the canyon also might have blocked sediment transportation from the slope area to the abyssal basin.

\section{Controlling factors on the development of the Pearl River Canyon system}

High sediment input

It has long been observed that many submarine canyons are spatially connected to rivers on the continent. Onshore 


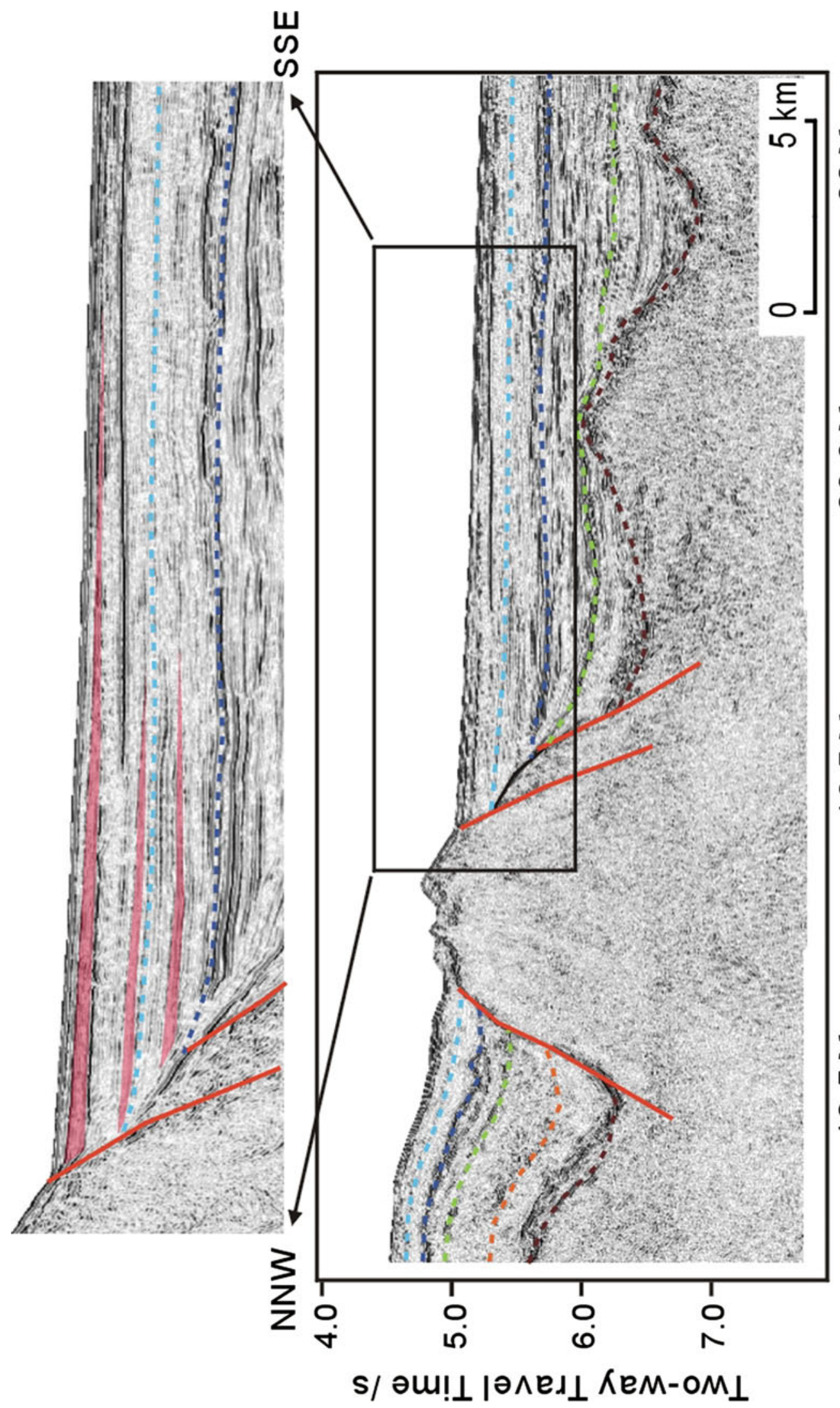

$\stackrel{t}{\circ}$

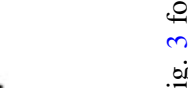


rivers may connect canyons directly into the river mouth (Babonneau et al. 2002; Yu et al. 2009; Hsiung and Yu 2012) or erode their way into a continental shelf during a lowstand period (Damuth 1994; Popescu et al. 2004; Anderson 2005; Ding et al. 2010). Hyperpycnal currents generated in rivers drive sediment transport on the sea bottom, thereby favoring the formation of canyons or channels. Taking into account the location of our study zone offshore from the Pearl River, the largest river in southern China, the possible effect of the river sediment supply on the canyon development has to be considered. The annual sediment discharge of the Pearl River is about $7 \times 10^{7} \mathrm{t}$ (Wang 1995), and the deposition of terrestrial sediments in the Pearl River Delta on the continental shelf has a 30-Ma history (Shao et al. 2008). Neodymium isotope studies from ODP Site 1148 in the lower slope show that the sediments originated in southern China, similar to those of the Pearl River Delta (Clift et al. 2002b; Li et al. 2003). This proves that the Pearl River has been the sedimentary source for the Pearl River Delta on the continent shelf for a long time, as well as the continental slope area.

Sea level change is another important factor to consider, since relative sea level changes are responsible for the location at which sediment input from onshore rivers is deposited (Farre et al. 1983). During highstands, the head of the Pearl River Canyon is separated from the coastline by a wide shelf. Most of the terrestrial input would accumulate in the Pearl River Delta on the continental shelf. Then, as sea level has fallen, the continental shelf would be partially exposed, the coastline would be located near the shelf-edge, and river sediment discharge would move towards the shelf edge. Hyperpycnal currents generated in the river would directly drive sediment transportation in the slope area and the abyssal basin.

A relative sea level change curve of the PRMB since $28 \mathrm{Ma}$ has been built based on a high-resolution quantitative nanofossil stratigraphic study (Pang et al. 2007) (Fig. 2). The curve reveals 19 eustatic periods since that time, during which sea level dropped to the shelf break eight times. High-frequency lowstand events in Neogene forced the paleo-Pearl River to run across the continental shelf and discharge its sediments at the shelf edge. Highenergy processes, such as mass flows or channelized turbidity flows, would have been common, thereby favoring canyon/channel formation.

Relative sea level changes have also been argued as one of the critical factors controlling deposition patterns inside submarine canyons (Gingele et al. 2004; Baztana et al. 2005; Antobreh and Krastel 2006; Gong et al. 2011). Eustatic changes in the South China Sea contributed to longterm repeated cut-and-fill events of varying magnitude of the Pearl River Canyon. During a sea level low, canyons are generally active, causing significant erosion and deep downcutting into the sediments with a high thalweg gradient. Such conditions favor thalweg and mass transport deposits along the canyon bottom, with a decreasing thalweg gradient, as well as the development of lowstand deepwater fans in the Baiyun Sag. Rising sea level, however, would reverse such depositional phenomena. Most of the terrestrial input would accumulate in the Pearl River Delta on the continental shelf and thalweg deposits would cease growing, as it does today (Zong et al. 2009).

\section{Structural controls}

The importance of underlying structures in controlling the formation and evolution of morphological features and sediment accumulation has long been appreciated. Several studies have illustrated the influence of tectonic deformation in controlling canyon location, orientation and morphology (Popescu et al. 2004; Yu et al. 2009; Dantec et al. 2010). In the case of the Pearl River Canyon system, Cenozoic tectonics also have played a critical role in canyon location and formation.

It is generally accepted that continental fragments, including the Dangerous Grounds and the Reed Bank, separated from the South China continent by seafloor spreading about $30 \mathrm{Ma}$ (Briais et al. 1993; Cullen et al. 2010). Terrigenous sediments began to be transported from the continental shelf area into the abyssal basin, which were likely to downcut and erode the continental slope area and form numerous small-scale linear channels. Canyons in a passive continental margin generally develop a sinuous course as the gradient reduces, much as a river does on land. However, the Pearl River Canyon and the group of canyons in the northern part of the Baiyun Sag, generally are oriented along a straight NW-SE course. Our seismic profile has confirmed the presence of several faults cutting vertically beneath the thalwegs (Figs. 5, 6), and some of these faults lie directly beneath buried channels (Fig. 6b). There is some confidence in the direct relationship between these faults and the location of buried channels. We cannot disregard the possibility that this major structural unit, consisting of NW-SE oriented faults, may focus erosion, and the formation of canyons or channels in the study area. Previous studies show that these faults were active throughout the Tertiary (Sun et al. 2005, 2009), and this is also supported by our seismic data (Figs. 5, 6). These faultcontrolled zones of weakness might have pre-determined the location of the distal canyon and also facilitated erosional downcutting during its formative stages. This would explain why the upper reaches of the Pearl River Canyon and canyons in the slope area north of the Baiyun Sag are generally oriented NW-NNW.

The Cenozoic evolution of the Baiyun Sag, where the main part of the Pearl River Canyon system is located, also 
has strongly affected the development of the canyon. Studies of the regional rifting architecture show that the Baiyun Sag features ductile deformation with composite grabens and short, small-vertical-offset faults. Sun et al. (2009) conjectured that the slope area may overlie a relatively warmer and thinner lithosphere than the shelf area owing to stretching and mantle upwelling associated with continental rifting. During the following thermal cooling period (since the Miocene), the Baiyun Sag has been dominated by rapid thermal subsidence, which has been proved by the analysis of the basin filling history and sedimentary structures (Zhou et al. 2009). The continental shelf break migrated from south to north of the Baiyun Sag and has been stable since. The negative relief in the area has controlled the orientation of the Pearl River Canyon, and the long-term subsidence of the Baiyun Sag has resulted in a broad U-shaped thalweg, which received the bulk of the sediments.

Why more erosion in the east wall?

It is notable that there are always more erosional features in the eastern walls of the canyons. The morphologies of the modern canyons show steeper walls on the eastern flanks, as well as a right-hand migrating stacked pattern of buried channels. This might suggest some consistent external control on the migration of these canyons.

High-energy marine processes, such as ocean currents, waves, and tides, can erode the seabed and trigger instability events (Shanmugam 2003). According to previous studies, the ocean current system in the northern South China Sea is complex owing to the combined influence of monsoon-driven surface currents and the South China Branch of Kuroshio current (Su 2004; Xue et al. 2004; Shao et al. 2004). Most of the complex surface currents are elongated parallel or sub-parallel to the continental margins (Shao et al. 2004), among which is a consistent northeastward current named the South China Sea Warm Current (Guan 1978). This current straddles the shelf break region (Guan 1978; Hsueh and Zhong 2004; Xue et al. 2004). Zhu et al. (2010) suggested that this northeastwarddirected intermediate current has consistently existed at least from the middle Miocene to the present in the study area, and forced the canyons to migrate to the northeast during highstand periods. We agree that the group of canyons in the slope area north of the Baiyun Sag has been influenced by this northeastward current, as is the case for rifted margins in the Gabon Basin of West Africa (Rasmussen 1994) and the Otway Basin in Australia (Leach and Wallace 2001). Those submarine canyons display consistent offsets of canyon cutting events that are congruent with the flow direction of past bottom currents.
The effect of the northeastward South China Sea Warm Current decreases as water depth increases. Previous studies have documented variations in the intensity with water depth, showing that it is much stronger in shallow water $(40 \mathrm{~cm} / \mathrm{s}$ from 10 to $100 \mathrm{~m}$ water depth) than in deep water $(4 \mathrm{~cm} / \mathrm{s}$ at $800 \mathrm{~m}$ water depth) (Guan and Fang, 2006). This might explain why the horizontal migration distance is reduced from canyon head to deep slope areas. As for the upper reach of the Pearl River Canyon, the water depth could reach $1,000 \mathrm{~m}$ with limited current control. Both the morphologies of the modern canyon and the stacking pattern of underlying buried channels (Fig. 6a) are irregular. Erosion and deposition within channels has developed on both flanks, without obvious lateral accretionary packages. However, we cannot disregard the possibility that further landward the Pearl River Canyon might also features a migrating stacking pattern similar to that seen in the group of canyons in the slope area north of the Baiyun Sag, although the possibility of preserving a migrating pattern is somewhat reduced for the decreasing subsidence amount towards the coast (Clift et al. 2002b, 2006).

\section{Origin and sedimentary processes}

Well-developed buried channels (even prior to $16.5 \mathrm{Ma}$, as shown in Fig. 5) provide a long historical record for the development of the Pearl River Canyon system. We support the suggestion that these canyons originated in conjunction with the opening of the South China Sea and the subsequent thermal subsidence on its northern continental margin. Past research has provided evidence for the extraordinarily rapid and persistent thermal subsidence in the Baiyun Sag since the Miocene (Clift and Lin 2001; Clift et al. 2002a; Hayes and Nissen 2005; Zhou et al. 2009). The shelf break was originally located more to the south at the opening of the South China Sea $\sim 30 \mathrm{Ma}$, and subsequently has migrated north of the Baiyun Sag, where it remains.

At $21 \mathrm{Ma}$, a major eustatic event occurred when sea level fell to the shelf break, exposing the continental shelf (Fig. 2). At that time, the paleo-Pearl River would have run across the continental shelf to the shelf break, allowing direct fluvial sediment delivery to the shelf edge and slope. The pre-canyon rills would be eroded by these sediment flows initiated at sites on the upper slope and over steepened by sedimentation. Rapid subsidence since $21 \mathrm{Ma}$ in the Baiyun Sag would also increase the slope gradient and triggered instability events like slumping and sliding. Sediments in the form of slides, slumps, and flows incised the upper continental slope and formed the canyons. The evolution of these sediment failures finally formed a 
headward-eroding canyon that advances upslope along the rills by sediment-flow-driven retrogressive failure. Preexisting NW-SE-oriented faults might have defined the upper reach of the Pearl River Canyon along a linear course, as similar faults likely did with the linear canyons in the slope area north of the Baiyun Sag. However, observed geometries and sedimentary structures indicate that the canyons in the slope area north of the Baiyun Sag are the main sediment transport conduits in the region, instead of the upper reach of the Pearl River Canyon. The persistent and rapid subsidence made the Baiyun Sag a constant negative landform, on which the middle and lower reaches of the Pearl River Canyon generally developed, and trapped most sediments transferred through these canyons as sedimentary fans.

With the rise in sea level, the depocenter moved northward to the Pearl River Delta. Basal erosion and downcutting caused by turbidity currents was reduced. The upper reach of the Pearl River Canyon was in a deposition-dominated stage. In contrast, the canyons in the slope area north of the Baiyun Sag experienced a relative decrease in erosion by the turbidity currents. Sediments transported by northeastward traveling bottom currents began to erode the eastern walls, and formed lateral accretionary packages at the west, thereby resulting in the observed northeast migration of these features. With the subsequent fall in sea level, the study area would be erosion-dominated again with newly developed channels. Such episodic sea level changes resulted in the interplay of downslope turbidity currents and bottom currents, which contributed to the change between the vertical aggradation and lateral migration developed in the canyons. These stacked buried channels in the slope area north of the Baiyun Sag correspond to the vertical-stacked deep-water fan in the Baiyun Sag.

\section{Conclusions}

1. The Pearl River Canyon system is the largest shelfindenting one on the northern continental margin of the South China Sea, including the Pearl River Canyon which displays three distinct trends, and seventeen sub-linear NNW-SSE oriented canyons developed in the slope area north of the Baiyun Sag. All of these canyons play significant roles in the sedimentary processes of the Pearl River Canyon system. It is a modern canyon system with a long evolutionary history.

2. The upper reach of the Pearl River Canyon has an irregular $U$ shape with a shallowly incised course that indicates a present-day deposition-dominated situation and weak mass transportation. In contrast, the slope area north of the Baiyun Sag features high slope gradients, a complex geomorphology, and intensively developed canyons. These deeply cut canyons are $\mathrm{V}$-shaped at the canyon heads and widen to U shapes downstream. They are asymmetrical with steep walls on their eastern flanks and stepped and curved walls on the western sides caused by slumps and slides. This evidence suggests that these canyons currently are the main conduits for terrigenous sediment transport from the continental shelf to the lower slope and abyssal basin, rather than the upper reach of the Pearl River Canyon. The middle and low reaches of the Pearl River Canyon have extremely wide $U$ shapes, and seismic reflections suggest that they are in a stage dominated by long-term deposition. They appear to develop just along the deepest part of the negative relief of the Baiyun Sag.

3. Seismic profiles show vertically stacked buried channels beneath the modern canyons. Thus, the Pearl River Canyon system has not been formed in a catastrophic single-phase event, but rather have evolved in a cyclical way, with several cut and fill phases of varying magnitude. A constant northeastward traveling bottom current during highstands and turbidity currents during lowstands jointly shaped the unidirectional development of the buried channels in the slope area north of the Baiyun Sag; the effect of the former decreased with increasing water depth. The upper reach of the Pearl River Canyon, which is located in a deeper area, has no regular stacking pattern of buried channels. The episodically buried channels suggest a long history of transfer conduits on the shelf, which have distinctive corresponding relationships with the vertically stacked deep-water fans in the middle reach of the Pearl River Canyon.

4. Eustasy, sediment supply, and Cenozoic tectonics have all played integrated roles during the formation of the Pearl River Canyon system. Rapid subsidence in the Baiyun Sag that followed seafloor spreading in the South China Sea shaped the negative landform in this area, and resulted in the south-to-north migration of the shelf break. Episodic lowstand sea levels after the Miocene would have repeatedly exposed the continental shelf either partially or entirely, and the paleo-Pearl River would have run across the shelf and reached the shelf break, allowing direct fluvial sediment delivery to the shelf edge. Sediment flows would have incised the axial thalweg, causing sediment failure both laterally on the flanks and at the canyon headwall, and might have initiated the formation of the Pearl River Canyon and canyons in the slope area north of the Baiyun Sag. The NW-SE-oriented faults of the shelf margin would have defined the trend of the canyon/channel. 
5. Compared with other canyons on passive margins with extensive deep-water fans at the canyon mouth, such as the Amazon, Mississippi, Indus, and Bengal fans (Kottke et al. 2003; Oliveira et al. 2007; Harris and Whiteway 2011), the deep-water fan of the Pearl River Canyon system is relatively small. Long-term subsidence of the Baiyun Sag caused the middle and lower reaches of the Pearl River Canyon to trap most of the terrigenous sediments transferred through the upper reach and through channels in the northern slope area, leaving only small amounts of sediment to reach the abyssal basin and form deep sea fans at the mouth.

Acknowledgments We want to thank Peter Clift and an anonymous reviewer for their helpful reviews that permitted to improve the manuscript. We are grateful to the technical staff from KLSB and SIO who took part in the field work at sea. Yinxia Fang, Aiguo Ruan, Yong Tang, Chongzhi Dong and Zhenli Wu from SIO, Hangzhou are thanked for the stimulating discussions on this paper. This work was financially supported by the National Natural Science Foundation of China (No.91028006, 40806023), the Scientific Research Fund of the SIO, SOA (No.JT1202), and the Public Science and Technology Research Funds Project of Ocean (No.201205003).

Open Access This article is distributed under the terms of the Creative Commons Attribution License which permits any use, distribution, and reproduction in any medium, provided the original author(s) and the source are credited.

\section{References}

Anderson DE (2005) Holocene fluvial geomorphology of the Amargosa River through Amargosa Canyon, California. Earth Sci Rev 73:291-307

Antobreh AA, Krastel S (2006) Morphology, seismic characteristics and development of Cap Timiris Canyon, offshore Mauritania: a newly discovered canyon preserved-off a major arid climatic region. Mar Petrol Geol 23:37-59

Babonneau N, Savoye B, Cremer M, Klein B (2002) Morphology and architecture of the present canyon and channel system of the Zaire deep-sea fan. Mar Petrol Geol 19:445-467

Baztana J, Berne S, Olivet JL, Rabineau M, Aslanian D, Gaudin M, Rehault JP, Canals M (2005) Axial incision: the key to understand submarine canyon evolution (in the western Gulf of Lion). Mar Petrol Geol 22:805-826

Briais A, Patriat P, Tapponnier P (1993) Updated interpretation of magnetic anomalies an seafloor spreading stages in the South China Sea: implications for the tertiary tectonics of Southeast Asia. J Geophys Res 98:6299-6328

Carson B, Baker ET, Hickey BM, Nittrouer CA, De-Master DJ, Thorbjarnarson KW, Snyder GW (1986) Modern sediment dispersal and accumulation in Quinault submarine canyon-a summary. Mar Geol 71:1-13

Clift P (2006) Controls on the erosion of Cenozoic Asia and the flux of clastic sediment to the ocean. Earth Planet Sci Lett 241(3-4):571-580

Clift P, Lin J (2001) Preferential mantle lithospheric extension under the South China margin. Mar Petrol Geol 18:929-944

Clift P, Lin J, Barckhausen U (2002a) Evidence of low flexural rigidity and low viscosity lower continental crust during continental break-up in the South China Sea. Mar Petrol Geol 19:951-970

Clift P, Lee JL, Clark MK, Blusztajn J (2002b) Erosional response of South China to arc rifting and monsoonal strengthening, a record from the South China Sea. Mar Geol 184(3-4):207-226

Cullen A, Reemst P, Henstra G, Gozzard S, Ray A (2010) Rifting of the South China Sea: new perspective. Petrol Geosci 16:273-282

Damuth JE (1994) Neogene gravity tectonics and depositional processes on the deep Niger Delta continental margin. Mar Petrol Geol 11(3):321-346

Dantec NL, Hogarth LJ, Driscoll NW, Babckck JM, Barnhardt WA, Schwab WC (2010) Tectonic controls on nearshore sediment accumulation and submarine canyon morphology offshore La Jolla, Southern California. Mar Geol 268:115-128

Deptuck ME, Steffens GS, Barton M, Pirmez C (2003) Architecture and evolution of upper fan channel-belts on the Niger Delta slope and in the Arabian Sea. Mar Pet Geol 20:649-676

Ding WW, Li JB, Li J (2010) Forming mechanism of the submarine canyon on the north slope of the South China Sea. J Mar Sci 28:26-31 (in Chinese)

Farre JA, McGregor BA, Ryan WBF, Robb JM (1983) Breaching the shelfbreak passage from youthful to mature phase in submarine canyon evolution. Spec Publ Soc Econ Paleontol Mineral 33:25-39

Fuh SC, Chern CC, Liang SC, Yang YL, Wu SH, Chang TY, Lin JY (2009) The biogenic gas potential of the submarine canyon systems of Plio-Pleistocene foreland Basin, southwestern Taiwan. Mar Petrol Geol 26:1087-1099

Gingele FX, Deckker PD, Hillenbrand CD (2004) Late quaternary terrigenous sediments from the Murray Canyons area, offshore South Australia and their implications for sea level change, palaeoclimate and palaeodrainage of the MurrayeDarling Basin. Mar Geol 212:183-197

Gong CL, Wang YM, Zhu WL, Li WG, Xu Q, Zhang JM (2011) The Central Submarine Canyon in the Qiongdongnan Basin, northwestern South China Sea: architecture, sequence stratigraphy, and depositional processes. Mar Petrol Geol 28:1690-1702

Granata TC, Vidondo B, Duarte CM, Satta MP, Gracia M (1999) Hydrodynamics and particles transport associated with a submarine canyon of Blanes (Spain), NW Mediterranean Sea. Cont Shelf Res 19:1249-1263

Guan BX (1978) The warm current in the South China Sea. Oceanologia Et Limnologia Sinica 9:117-127

Guan BX, Fang GH (2006) Winter counter-wind currents off the southeastern China coast: a review. J Oceanogr 62:1-24

Hagen RA, Vergara H, Naar DF (1996) Morphology of San Antonio submarine canyon on the central Chile forearc. Mar Geol 129: 197-205

Harris PT, Whiteway T (2011) Global distribution of large submarine canyons: geomorphic differences between active and passive continental margins. Mar Geol 285:69-86

Hayes DE, Nissen SS (2005) The South China sea margins: implications for rifting constrasts. Earth Planet Sci Lett 237: $601-616$

He YL, Xie XN, Kneller BC, Wang ZF, Li XS (2012) Architecture and controlling factors of canyon fills on the shelf margin in the Qiongdongnan Basin, northern South China Sea. Mar Petrol Geol. doi:10.1016/j.marpetgeo.2012.03.002

Hsiung KH, Yu HS (2012) Sediment dispersal system in the TaiwanSouth China Sea collision zone along a convergent margin: a comparison with the Papua New Guinea collision zone of the western Solomon Sea. J Asian Earth Sci. doi:10.1016/j.jseaes. 2012.10.006

Hsueh Y, Zhong LJ (2004) A pressure-driven South China Sea warm current. J Geophys Res Oceans 109:C09014 
Jin QH (1989) Geology and oil gas resources in South China Sea. Geology Publishing House, Beijing, pp 84-111 (in Chinese)

Klaus A, Taylor B (1991) Submarine canyon development in the IzuBonin forearc: a SeaMARC II and seismic survey of Aoga Shima Canyon. Mar Geophys Res 13:131-152

Kottke B, Schwenk T, Breitzke M, Wiedicke M, Kudrass HR, Spiess V (2003) Acoustic facies and depositional processes in the upper submarine canyon swatch of no ground (Bay of Bengal). Deep Sea Res II 50:979-1001

Leach AS, Wallace MW (2001) Cenozoic submarine canyon systems in cool water carbonates from the Otway Basin, Victoria, Australia. In: PESA East Australasian basins symposium, Melbourne, Victoria, Australia, pp 465-473

Li X, Wei G, Shao L, Liu Y, Liang X, Jian Z, Sun M, Wang P (2003) Geochemical and $\mathrm{Nd}$ isotopic variations in sediments of the South China Sea; a response to Cenozoic tectonism in SE Asia. Earth Planet Sci Lett 211(3-4):207-220

Li G, Piper DJW, Campbell DC, Mosher D (2012) Turbidite deposition and the development of canyons through time on an intermittently glaciated continental margin: the Bonanza Canyon system, offshore eastern Canada. Mar Petrol Geol 29:90-103

Liu BJ, Yuan LZ, Shen J, Lian SY, He M, Pang X, Shu Y, Peng DJ (2006) Northern continental slope palaeogeomorphology and deep-water fan system response of Pearl River since 13.8 Ma, South China Sea. Acta Sedimentologica Sinica 24:476-482 (in Chinese)

Luedmann T, Wong HK (1999) Neotectonic regime on the passive continental margin of the northern South China Sea. Tectonophysics 311:113-138

Mayall M, Jones E, Casey M (2006) Turbidite channel reservoirskey elements in facies prediction and effective development. Mar Petrol Geol 23:821-841

McHargue T, Pyrcz MJ, Sullivan MD, Clark JD, Fildani A, Romans BW, Covault JA, Levy M, Posamentier HW, Drinkwater NJ (2011) Architecture of turbidite channel systems on the continental slope: patterns and predictions. Mar Petrol Geol 28:728-743

Olabode SO, Adekoya JA (2008) Seismic stratigraphy and development of Avon Canyon in Benin (Dahomey) basin, southwestern Nigeria. J Afr Earth Sci 50:286-304

Oliveira A, Santos AL, Rodrigues A, Vitorino J (2007) Sedimentary particle distribution and dynamics on the Nazare canyon system and adjacent shelf (Portugal). Mar Geol 246(2-4):105-122

Pang X, Chen CM, Peng DJ, Zhu M, Shu Y, He M, Shen J, Liu BJ (2007) Sequence Stratigraphy of Deep-water Fan System of Pearl River, South China Sea. Earth Sci Frontiers 14:220-229

Peng DJ, Chen CM, Pang X, Zhu M, Yang F (2004) Discovery of deep-water fan system in South China Sea. Acta Petrolei Sinaca 25:17-23 (in Chinese)

Peng DJ, Pang X, Chen CM, Zhu M, Huang XL, Shu Y (2006) The characteristics and controlling factors for the formation of deepwater fan system in South China Sea. Acta Sedimentol Sin 24:10-18 (in Chinese)

Popescu I, Lericolais G, Panin N, Normand A, Dinu C, Drezen EL (2004) The Danube submarine canyon (Black Sea) morphology and sedimentary processes. Mar Geol 206:249-265

Posamentier HW, Kolla V (2003) Seismic geomorphology and stratigraphy of depositional elements in deep-water settings. Mar Petrol Geol 20:677-690

Puig P, Ogston AS, Mullenbach BL, Nittrouer CA, Sternberg RW (2003) Shelf-to-canyon sediment-transport processes on the Eel continental margin (northern California). Mar Geol 193:129-149

Rasmussen ES (1994) The relationship between submarine canyon fill and sea level change; an example from middle Miocene offshore Gabon, West Africa. Sediment Geol 90:61-75
Ru K, Pigott JD (1986) Episodic rifting and subsidence in the South China Sea. AAPG Bull 70:1136-1155

Shanmugam G (2003) Deep-marine tidal bottom currents and theri reworked sands in modern and ancient submarine canyons. Mar Petrol Geol 20:471-490

Shao L, Li XH, Wang PX, Jian ZM, Wei GJ, Pang X, Liu Y (2004) Sedimentary record of the tectonic evolution of the South China Sea since the oligocene-evidence from deep sea sediments of ODP site 1148. Adv Earth Sci 19:539-541 (in Chinese)

Shao L, Pang X, Qiao PJ, Chen CM, Li QY, Miao WL (2008) Sedimentary filling of the Pearl River Mouth Basin and its response to the evolution of the Pearl River. Acta Sedimentol Sin 26:179-185 (in Chinese)

Stow DAV, Mayall M (2000) Deep-water sedimentary systems: new models for the 21st century. Mar Petrol Geol 17:125-135

Su JL (2004) Overview of the South China Sea circulation and its influence on the coastal physical oceanography outside the Pearl River Estuary. Cont Shelf Res 24:1745-1760

Sun Z, Pang X, Zhong ZH, Zhou D, Chen CM, Hao HJ, He M, Huang CJ, Xu HH (2005) Dynamics of tertiary tectonic evolution of the Baiyun Sag in the Pearl River Mouth Basin. Earth Sci Frontiers 12(4):489-498 (in Chinese)

Sun Z, Zhong ZH, Keep M, Zhou D, Cai DS, Li X, Wu S, Jiang J (2009) 3D analogue modeling of the South China Sea: a discussion on breakup pattern. J Asian Earth Sci 34:544-556

Wang PX (1995) South China Sea since 150 Ka. Tongji University Press, Shanghai, p 12 (in Chinese)

Wang P, Prell WL, Blum P, Arnold EM, Buehring CJ, Chen M-P, Clemens SC, Clift PD, Colin CJG, Farrell JW, Higginson MJ, Jian Z, Kuhnt W, Laj CE, Lauer-Leredde C, Leventhal JS, Li A, Li Q, Lin J, McIntyre K, Miranda CR, Nathan SA, Shyu JP, Solheid PA, Su X, Tamburini F, Trentesaux A, Wang L (2000) In: Proceedings of ocean drilling program, initial report. Ocean Drilling Program, College Station, p 184

Wang HR, Wang YM, Qiu Y, Peng XC, Liu YY (2008) Geomorphology and its control of deep-water slope of the margin of the South China Sea. Acta Oceanologica Sinica 30:70-79 (in Chinese)

Xue HJ, Chai F, Pettigrew N, Xu DY, Shi M, Xu JP (2004) Kuroshio intrusion and the circulation in the South China Sea. J Geophys Res Oceans 109:C02017

Yu HS, Chiang CS, Shen SM (2009) Tectonically active sediment dispersal system in SW Taiwan margin with emphasis on the Gaoping (Kaoping) Submarine Canyon. J Mar Syst 76:369-382

Zheng XD, Zhu M, He M, Li HW, Lian SY, Zhang X (2007) Prediction of Liwan deep submarine fan sand body distribution, Baiyun Sag, Pearl River Mouth Basin. Petrol Explor Dev 34:529-533 (in Chinese)

Zhou D, Ru K, Chen HZ (1995) Kinematics of Cenozoic extension on the South China Sea continental margin and its implications for the tectonic evolution of the region. Tectonophysics 251:161-177

Zhou D, Sun Z, Liao J, Zhao ZX, He M, Wu XJ, Pang X (2009) Filling history and post-breakup acceleration of sedimentation in Baiyun Sag, Deepwater Northern South China Sea. J Earth Sci 20:160-171

Zhu MZ, Graham S, Pang X, McHargue T (2010) Characteristics of migrating submarine canyons from the middle Miocene to present: implications for paleoceanographic circulation, northern South China Sea. Mar Petrol Geol 27:307-319

Zong Y, Huang G, Switzer A, Yu F, Yim WWS (2009) An evolutionary model for the Holocene formation of the Pearl River delta, China. The Holocene 19:129-141 